3. Коломієць Я.Л. Правове регулювання обмежень у здійсненні виробничо-господарської діяльності сільськогосподарських товаровиробників: дис. ... канд. юрид. наук: 12.00.06. Харків, 2015. 214 с.

4. Шпомер А.І. Ліцензування господарської діяльності (господарсько-правовий аспект): дис. ... канд. юрид. наук: 12.00.04. Київ, 2006. $232 \mathrm{c}$.

5. Господарський кодекс України: Закон України від 16.01.2003 р. № 436-IV / Верховна Рада України. URL: http://zakon2.rada.gov.ua/ laws/show/436-15.

DOI https://doi.org/10.30525/978-9934-588-92-1-45

\title{
PROBLEMATIC ISSUES OF LEGAL TERMINATION OF CRYPTOCURRENCIES
}

\author{
Polishchuk N. Yu. \\ Postgraduate Student \\ V. Mamutov Institute of Economic and Legal Research \\ of the National Academy of Sciences of Ukraine \\ Kyiv, Ukraine
}

In recent years, in the development of the world economy in general and its financial system in particular, we have seen phenomenal changes and transformations associated with the emergence of cryptocurrencies. The question is whether the cryptocurrency can cease to exist, as well as whether there is a legal explanation for this. As there is currently no unified legal regulation of cryptocurrencies, the possible reasons for terminating cryptocurrencies should be taken into account when drafting legislation. It is extremely difficult to manipulate the cryptocurrency network. Deleting or overwriting a block of already spent bitcoins becomes impossible due to decentralization, chronological and computational, energy-intensive characteristics of the blockchain. A hacker who wants to change a distributed bitcoin book or any other network based on blockchain technology will have to hack not one, but more than half of the participating computers, the so-called «51\% attack», in which a group of miners theoretically controls more half of the total network capacity. By running most of the entire network, this criminal group of hackers can dominate the rest of the network to falsify records. However, such an attack on 
cryptocurrencies will require enormous effort, money and computing power, which makes such a possibility extremely unlikely. A 51\% attack is a PoW blockchain vulnerability that allows an attacker to take control of transaction confirmation and block generation. Of course, a large mining pool can find additional resources and launch an attack on the selected cryptocurrency. Based on the data of the «51crypto» service, a study was conducted «51\% Attack Cost» compiled a table of cryptocurrency and the price of the attack per hour (cost). According to data obtained in October 2020, you can see that to attack the cryptocurrency bitcoin, you need to spend about $\$ 592,000$ per hour [1]. In 2020, it makes no sense to attack cryptocurrencies, it will be too expensive and extremely difficult in organizational terms.

Cryptocurrency is considered resistant to hacking because the blockchain system is constantly viewed by the entire network. Thus, attacks on the blockchain itself are very unlikely. Due to its decentralized, distributed nature, blockchain technology is well suited for protection against hacker attacks. However, cryptocurrency wallets, where owners' cryptocurrencies are stored, are vulnerable to such attacks. Any site where the payment is to take place today can cause the loss of cryptocurrencies. For example, in July 2017, when one of the popular web wallets for cryptocurrencies Ethereum Classic, cryptocurrencies from e-wallets of many users suddenly began to disappear.

Cryptocurrency mining is becoming unprofitable. In 2012 and 2016, there was an algorithmic reduction of the fee for bitcoin mining by half, but this was offset by a sharp rise in the price of cryptocurrency. At the beginning of 2019, mining on the latest generation of equipment with the price of electricity at the level of industrial areas of China at 5 US cents per $\mathrm{kWh}$, works in a small plus on large mining farms. The last Bitcoin halving (the reduction in the fee for bitcoin mining) took place on May 11, 2020, and the next halving will likely occur in 2024, which will make mining unprofitable without an increase in its price.

There is also a possibility that cryptocurrency may be banned by the state. That is, in fact, it will exist, but its use will be limited by state power. Because cryptocurrencies are decentralized, the network as such cannot be shut down by a single government. However, governments have previously tried to ban cryptocurrencies or at least restrict their use in the relevant jurisdiction. The National Bank of Ukraine in a letter dated December 8, 2014 № 29-208 / 72889 stated that Bitcoin is a monetary surrogate that has no real value, and recommended that citizens use the services of only those payment systems that are paid by the National Bank [2]. Later, on March 2, 2018, the NBU officially revoked this Letter [3].

On December 5, 2013, the Central Bank of China banned banks and other financial institutions from conducting transactions with 
cryptocurrencies, and Internet services undertook to comply with anti-money laundering rules. The Chinese government emphasizes that cryptocurrencies and tokens are not payment instruments issued by monetary institutions, they do not have «legal or monetary properties» and the legal status of money. Due to this, their distribution and use as a currency is unacceptable [4]. That is, the government is trying to destroy the cryptocurrency as much as possible. Despite strict legal restrictions in China, cryptocurrency users have become fewer, but they have not disappeared completely.

Conclusions:

1) As there is no single unified approach to the legal regulation of cryptocurrencies, the reasons for their termination should be taken into account when drafting legislation.

2) Technologically, cryptocurrency can not disappear, but theoretically there are threats to its existence - an attack of $51 \%$, a ban at the state level, unprofitable mining. Cryptocurrency wallets are vulnerable to hacking.

3) Despite the official ban on the use of cryptocurrencies in China, activities related to the use of cryptocurrencies have not ceased. Therefore, experience testifies to the futility of bans. Creating an effective legal framework will reduce risks for cryptocurrency users and increase the level of transparency for the state.

\section{References:}

1. PoW 51\% «Attack Cost». URL: https://www.crypto51.app/

2. Lyst Nacionalnogo banku Ukrainy (2014) Schodo vidnesennja operations with virtual currency / cryptocurrency Bitcoin to operations with trade in foreign currency 08 grud. 2014 № 29-208 / 72889 [The letter of the National Bank of Ukraine "On attributing operations with" virtual currency Bitcoin cryptocurrency to foreign currency trading operations "from December 8 2014, [29-208 / 72889]. URL: http://zakon2.rada.gov.ua/ lavs/shov/v2889500 -14 (in Ukrainian)

3. Roz'yasnennya shhodo pravomirnosti vy'kory'stannya v Ukrayini «virtual'noyi valyuty'/kry'ptovalyuty'» Bitcoin. - Nacional'ny'j bank Ukrayiny' [Clarification regarding the legality of use in Ukraine "virtual currency / cryptocurrency» Bitcoin. - National Bank of Ukraine] URL: http://bank.gov.ua/control/uk/publish/article?art_id=11879608 (Accessed 10.10.2020) (in Ukrainian)

4. Chinese ICO Ban - What is in store for Investors? URL: https://medium.com/crypt-bytes-tech/chinese-ico-ban-what-is-instore-forchinese-icos-and-investors-aa729f567bb4 